\title{
Topographic and Habitat Use by Sympatric Barbary Sheep and Mule Deer in Palo Duro Canyon, Texas
}

\author{
C. DAVID SIMPSON AND GARY G. GRAY
}

\section{Abstract}

The topographic distribution of sympatric populations of Barbary sheep and mule deer was studied in the Dry Creek branch (65 $\mathbf{k m}^{2}$ ) of Palo Duro Canyon in the central Texas Panhandle from February 1977 through January 1979. Each of 529 Barbary sheep sightings and 337 mule deer sightings were recorded by topographic level and nonparmetric tests were used to evaluate the null hypothesis of no significant difference in distribution between Barbary sheep and mule deer in topographic level or habitat type. There was no significant difference between specles in spatial usage on a monthly basis when sightings on Bluff Sites were compared with those on Level Sites. When sightings on High Sites were compared with those on Low Sites, distributional patterns were significantly different only for February and November. There were significant seasonal differences between species in distribution by habitat type during the autumn and spring, but the aggregate distribution of sightings suggested that overall usage of space was not significantly different. These findings, when considered with the results of comparative diet studies, indicate the possibility of competition for mutally preferred forage plants. Other implications are also discussed.

Big game was scarce in Palo Duro Canyon during the first half of this century. This situation probably resulted from subsistence hunting by early settlers (Simpson and Leftwich 1978, 1981), habitat deterioration (Leftwich and Simpson 1978), the screwworm (Cephenemyia hominivorax) problem, and poor range condition and poaching during the drought years of the 1930's and 1950's (T.T. Christian pers. comm. 1979). In response to this situation, the Texas Parks and Wildlife Department released 268 mule deer (Odocoileus hemionus) in Palo Duro Canyon from 1949 through 1951 (DeArment 1971) and 85 more in 1964 (Evans 1964) to augment the small remnant population. Forty-four Barbary sheep (Ammotragus lervia), an exotic ungulate from North Africa, were introduced into the canyon in 1957-58. Because the Barbary sheep population appears to be increasing (Simpson et al. 1978), this study was conducted to determine the topographic distribution and habitat utilization of both species in Palo Duro Canyon as one component of the ecological relationship between these two sympatric ungulates.

When this research was conducted the authors were, respectively, associate professor and graduate research assistant, Department of Range and Wildlife Management, Texas Tech University, Lubbock 79409. C.D. Simpson's present address is 8, 2 Ist Avenue, Famona, Bulawayo, Zimbabwe, Africa. G.G. Gray is now assistant professor in the Department of Biological Sciences, Nort hern Illinois University, DeKalb 60115. Send reprint requests to Dr. Gray.

The authors thank Tom Christian and Kenneth Matthews of Claude, Texas, for access to the study area on their properties, and Drs. Henry A. Wright, J. Knox Jones, Jr., Ernest B. Fish, and Danny B. Pence, all of Texas Tech University, for comments on the manuscript.

This is Technical Paper No. T-9-258 of the College of Agricultural Sciences, Texas Tech University, which provided financial support for this study.

Manuscript received June 4, 1981.

\section{Study Area}

Palo Duro Canyon, a winding and irregular gorge approximately $97 \mathrm{~km}$ by $32 \mathrm{~km}$, located in the central Texas Panhandle at an elevation of $1048 \mathrm{~m}$, was formed by the erosive action of the Prairie Dog Town Fork of the Red River. The steep bluffs of the Caprock escarpment form canyon walls up to $244 \mathrm{~m}$ in vertical height. Erosion-resistant formations have been preserved as mesas, ledges, benches, or ridge fingers.

Five range sites were delineated on the study area corresponding to belts on a vertical rim-to-floor transect (Jacquot et al. 1965). Each site is characterized by a distinctive combination of geological strata, soil type, and topography. These 5 range sites constitute 4 topographic levels (Fig. 1), defined as follows: (1) the Deep Hardland of the High Plain above the canyon combined with the Mixed Land Slope abutting the rim comprises an upper level called the "Canyon Rim"; (2) high ledges on the Rough Breaks of the canyon walls, $30-45 \mathrm{~m}$ below the rim, were termed "High Benches"; (3) lower ledges on the canyon walls, generally $30-45 \mathrm{~m}$ above the canyon floor were designated "Low Benches"; and (4) the gently rolling Shallow Redland and Bottomland of the floor collectively called the "Canyon Floor." The 5 range sites and 4 topographic levels described represent 3 major big game habital types-the Canyon Rim, the Rough Breaks(Bluff Faces) that form the canyon walls, and the Canyon Floor.

The vegetation reflects this diversity and includes such mesic species as bottlebrush sedge (Carex hystricina), smooth horsetai]

\section{DRY CREEK STUDY AREA \\ PALO DURO CANYON, TEXAS \\ TOPOGRAPHIC LEVELS}

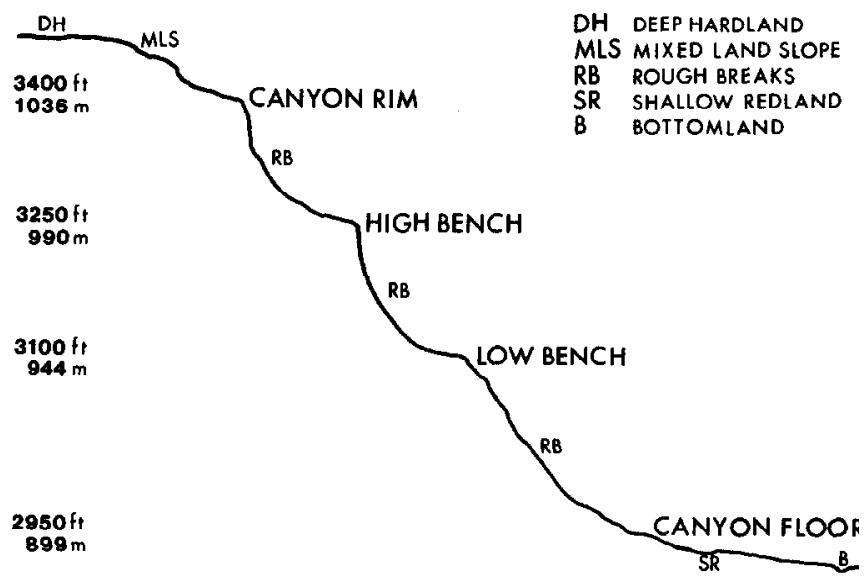

Fig. 1. Vertical profile of the Dry Creek Study area in Palo Duro Canyon Texas, showing the relationship of USDA Soil Conservation Servic range site classifications to the topographic levels defined in this study 
(Equisetum laevigatum) and cottonwoods (Populus deltoides), along stream beds on the canyon floor, as well as typical shortgrass prairie and semiarid plants. Wright (1978) traced the development of the flora of this region, and Rowell (1967) inventoried the vegetation of the Texas Panhandle and South Plains. Hampy (1978) surveyed plants on the Dry Creek study area $\left(34^{\circ} 58^{\prime} \mathrm{N}, 101^{\circ}\right.$ $31^{\prime} \mathrm{W}$ ) which is situated along the northern canyon rim, $39 \mathrm{~km}$ southeast of Amarillo, in Armstrong County.

\section{Methods}

A field and adjacent pasture which abut the canyon rim were observed from a blind for 1 hour beginning at sunrise each field day, after which a standard observation route (SOR) was hiked following the northern canyon rim along an east to west arc. Search observations were made with $8 \times 40-\mathrm{mm}$ binoculars from fixed points on the rim and ridge fingers that provided good visibility of adjacent ridge fingers, bluff faces, and the canyon floor.

For each sighting of Barbary sheep or mule deer, the topographic level was recorded. Sightings for the 2 field years were combined on a monthly basis and then arranged in a series of $2 \times 4$ contingency tables-ungulate species versus topographic levelsand examined for monthly, seasonal, and overall differences. Contingency tables were recast as two series of $2 \times 2$ tables in which sightings on High Sites (Canyon Rim and High Benches) were examined in relation to Low Sites (Low Benches and Canyon Floor), and sightings on Bluff Sites (High Benches and Low Benches) were compared with Level Sites (Canyon Rim and Canyon Floor). The data were then evaluated in terms of the 3 big game habitats present (Canyon Rim, Rough Breaks, and Canyon Floor) to determine Barbary sheep and mule deer habitat preferences on a seasonal basis.

Chi-square tests (Siegel 1956) were used to evaluate null hypotheses $\left(\mathbf{H}_{\mathrm{o}}\right)$ of no significant difference between Barbary sheep and mule deer topographic distribution and seasonal habitat preference. The Fisher Exact Probability test (Siegel 1956) was used in a few cases where mule deer sample sizes were very small; and was used with the knowledge of Sokal and Rohlf's (1969:589) cautionary comment that this test was originally designed for a Model 111 test of independence in which both marginal totals are fixed by the experiment. The null hypotheses were rejected for values of $\hat{\alpha}$ $\leq 0.05$.

\section{Results}

Direct observations from the blind and SOR occupied 1246 hours on 271 field days from February 1977 through January 1979, and produced a total of 529 Barbary sheep sightings and 337 mule deer sightings. Analyses of monthly interactions of the 2 ungulate species with the 4 topographic levels were not possible because more than $20 \%$ of the cells in all monthly contingency tables had expected frequencies less than 5 (Siegel 1956:178).

The seasonal interaction of these ungulates with topographic levels showed that topographic distribution was significantly different $(p=0.016)$ during the spring (April, May, and June). Barbary sheep ( $\mathrm{N}=188$ sightings) utilized all levels, except the Canyon Floor (3.7\%), about equally during the spring, whereas mule deer $(\mathrm{N}=44$ sightings) were seen most of ten $(86.4 \%)$ on the benches of the canyon walls.

There was no difference between species $(p=0.83)$ in topographic level selection during the summer (July, August, and September). Barbary sheep ( $80.7 \%$ of 88 sightings) and mule deer (79.8\% of 109 sightings) were both concentrated on benches (the Rough Breaks) of the canyon walls.

During the autumn (October, November, and December), Barbary sheep were sighted most frequently on the benches of the canyon walls (75.7\% of 74 sightings) while mule deer spatial utilization was concentrated on the High Sites (i.e., the Canyon Rim or High Benches, $69.4 \%$ of 73 sightings). This difference was signifi-

Table 1. Monthly distributions of Barbary sheep and mule deer sightings in Palo Duro Canyon, Texas, showing no significant differences ( $p>0.05$ ) between these species in comparative spatial usage of Bluff as compared with Level topographic sites.

\begin{tabular}{|c|c|c|c|c|c|}
\hline Month & Topographic site & Barbary sheep & Mule deer & Statistical test & $p^{l}$ \\
\hline January & $\begin{array}{l}\text { Bluff } \\
\text { Level }\end{array}$ & $\begin{array}{r}16 \\
5\end{array}$ & $\begin{array}{l}5 \\
0\end{array}$ & FEP & $>0.30 \mathrm{~ns}$ \\
\hline February & $\begin{array}{l}\text { Bluff } \\
\text { Level }\end{array}$ & $\begin{array}{l}27 \\
19\end{array}$ & $\begin{array}{l}22 \\
24\end{array}$ & $x^{2}$ & $>0.30 \mathrm{~ns}$ \\
\hline March & $\begin{array}{l}\text { Bluff } \\
\text { Level }\end{array}$ & $\begin{array}{l}52 \\
60\end{array}$ & $\begin{array}{l}22 \\
38\end{array}$ & $x^{2}$ & $>0.30 \mathrm{~ns}$ \\
\hline April & $\begin{array}{l}\text { Bluff } \\
\text { Level }\end{array}$ & $\begin{array}{l}47 \\
41\end{array}$ & $\begin{array}{l}8 \\
4\end{array}$ & $x^{2}$ & $>0.50 \mathrm{~ns}$ \\
\hline May & $\begin{array}{l}\text { Bluff } \\
\text { Level }\end{array}$ & $\begin{array}{l}37 \\
22\end{array}$ & $\begin{array}{l}5 \\
0\end{array}$ & FEP & $>0.10 \mathrm{~ns}$ \\
\hline June & $\begin{array}{l}\text { Bluff } \\
\text { Level }\end{array}$ & $\begin{array}{r}34 \\
7\end{array}$ & $\begin{array}{r}17 \\
2\end{array}$ & $x^{2}$ & $>0.60 \mathrm{~ns}$ \\
\hline July & $\begin{array}{l}\text { Bluff } \\
\text { Level }\end{array}$ & $\begin{array}{r}33 \\
5\end{array}$ & $\begin{array}{l}32 \\
12\end{array}$ & $\chi^{2}$ & $>0.10 \mathrm{~ns}$ \\
\hline August & $\begin{array}{l}\text { Bluff } \\
\text { Level }\end{array}$ & $\begin{array}{r}20 \\
5\end{array}$ & $\begin{array}{r}33 \\
6\end{array}$ & $\chi^{2}$ & $>0.80 \mathrm{~ns}$ \\
\hline September & $\begin{array}{l}\text { Bluff } \\
\text { Level }\end{array}$ & $\begin{array}{r}21 \\
4\end{array}$ & $\begin{array}{r}22 \\
4\end{array}$ & $x^{2}$ & $>0.70 \mathrm{~ns}$ \\
\hline October & $\begin{array}{l}\text { Bluff } \\
\text { Level }\end{array}$ & $\begin{array}{r}18 \\
9\end{array}$ & $\begin{array}{l}23 \\
13\end{array}$ & $x^{2}$ & $>0.90 \mathrm{~ns}$ \\
\hline November & $\begin{array}{l}\text { Bluff } \\
\text { Level }\end{array}$ & $\begin{array}{r}17 \\
3\end{array}$ & $\begin{array}{l}8 \\
5\end{array}$ & $x^{2}$ & $>0.20 \mathrm{~ns}$ \\
\hline December & $\begin{array}{l}\text { Bluff } \\
\text { Level }\end{array}$ & $\begin{array}{r}21 \\
6\end{array}$ & $\begin{array}{l}13 \\
11\end{array}$ & $x^{2}$ & $>0.10$ \\
\hline
\end{tabular}

'Key: FEP = Fisher Exact Probability; $\chi^{2}$ chi-square; $n s=$ not statistically significant at the probability kevel indicated. 
cant $(p=0.008)$.

Through the winter months (January, February, and March), Barbary sheep (44.1\% of 179 sightings) and mule deer $(53.2 \%$ of 111 sightings) both utilized the Canyon Rim to a greater extent than other levels. Barbary sheep were also frequently seen on Low Benches (30.2\%) during this season, but secondary mule deer spatial usage was greater on High Benches (28.8\%) so the difference between species in winter topographic distribution was significant $(p=0.047)$.

To examine interactions on a monthly basis, contingency tables were recast-Barbary sheep and mule deer versus Bluff Sites (or Rough Breaks, i.e. High Benches and Low Benches) and Level Sites (Canyon Rim and Canyon Floor), and the 2 species versus High Sites (Canyon Rim and High Benches) and Low Sites (Low Benches and Canyon Floor). Analyses of these interactions showed that there was no difference $(p>0.147)$ in Barbary sheep sheep-mule deer versus Bluff Site-Level Site interaction for any month (Table 1). The ungulate species versus High Site-Low interaction indicated significant differences in topographic usage for only 2 months (Table 2). During February, Barbary sheep sightings $(\mathrm{N}=46)$ were equally divided between High and Low Sites, whereas $80.4 \%$ of 46 mule deer sightings were from High Sites $(p=$ $0.007)$. In November, $65 \%$ of Barbary sheep sightings $(N=20)$ were from Low Sites while $76.9 \%$ of mule deer sightings $(N=13)$ were from High Sites $(p=0.047)$. Totals for interactions of both species with all 4 topographic levels suggested no overall difference in spatial usage between Barbary sheep and mule deer $(p>0.05)$ (Table 3).

The data were then recast as $42 \times 3$ contingency tables in which sightings of Barbary sheep and mule deer were tabulated by big game habitat type on a seasonal basis. Over half of all Barbary sheep groups were sighted on the Rough Breaks (Bluff Faces) in every season, and most mule deer groups were also seen in this habitat during 3 of the 4 seasons (Table 4 ). A chi-square test suggested that the distribution of Barbary sheep and mule deer among the 3 habitat types was significantly different in the spring and fall $(p<0.01)$, but not during the summer or winter $(p>0.30)$. There was no overall difference between Barbary sheep and mule deer when seasonal data were combined $(p>0.50)$.

\section{Discussion}

DeArment (1971) observed that Barbary sheep showed a pronounced preference for the roughest and most precipitous terrain of the canyon and caprock almost inaccessible to humans, and that they easily negotiated sheer naked cliffs which usually constitute the break between upper and lower canyon terraces. Dickinson and Simpson (1980) reported that "slope" sites were preferred during spring and autumn seasons by Barbary sheep in southeastern New Mexico and were used extensively for bedding, whereas "bottom" sites were used mainly for feeding. Hampy (1978) found $24.5 \%$ of the Barbary sheep he sighted in Palo Duro Canyon in the summers (June through October) of 1976 and 1977 on the Canyon $\operatorname{Rim}, 71.5 \%$ on the Rough Breaks of the canyon walls, and $4 \%$ on the Canyon Floor. The preponderance of Barbary sheep sightings during this study were also from the Rough Breaks or bluffs which form the canyon walls (Table 4).

Anthony and Smith (1977) found that the distribution of mule deer in the San Cayetano Mountains of southeastern Arizona was not precisely determined by altitude or vegetation, and there were seasonal changes in use of various slope exposures and altitudes. Mule deer in the Dos Cabezas Mountains used all 3 altitudinalvegetational zones during at least part of this $2 \frac{1}{2}$-year (Anthony and Smith 1977). Approximately $50 \%$ of 11,581 mule deer observations by Mackie (1970) in the Missouri River breaks of northcentral Montana were on slopes greater than $11^{\circ}$. Only $7.9 \%$ were seen on slopes greater than $36^{\circ}$, and few animals were observed on

Table 2. Monthly distributions of Barbary sheep and mule deer sightings in Palo Duro Canyon, Texas, showing significant differences ( $p<0.05$ ) between these species in comparative spatial usage of High as compared with Low topographic sites for only 2 months of the year.

\begin{tabular}{|c|c|c|c|c|c|}
\hline Month & Topographic site & Barbary sheep & Mule deer & Statistical test ${ }^{1}$ & $p^{l}$ \\
\hline January & $\begin{array}{l}\text { High } \\
\text { Low }\end{array}$ & $\begin{array}{r}13 \\
8\end{array}$ & $\begin{array}{l}2 \\
3\end{array}$ & FEP & $>0.20 \mathrm{~ns}$ \\
\hline February & $\begin{array}{l}\text { High } \\
\text { Low }\end{array}$ & $\begin{array}{l}23 \\
23\end{array}$ & $\begin{array}{r}37 \\
9\end{array}$ & $\chi^{2}$ & $<0.02^{*}$ \\
\hline March & $\begin{array}{l}\text { High } \\
\text { Low }\end{array}$ & $\begin{array}{l}84 \\
28\end{array}$ & $\begin{array}{r}52 \\
8\end{array}$ & $\chi^{2}$ & $>0.10 \mathrm{~ns}$ \\
\hline April & $\begin{array}{l}\text { High } \\
\text { Low }\end{array}$ & $\begin{array}{l}60 \\
28\end{array}$ & $\begin{array}{r}12 \\
8\end{array}$ & $x^{2}$ & $>0.50 \mathrm{~ns}$ \\
\hline May & $\begin{array}{l}\text { High } \\
\text { Low }\end{array}$ & $\begin{array}{l}33 \\
26\end{array}$ & $\begin{array}{l}1 \\
4\end{array}$ & FEP & $>0.10 \mathrm{~ns}$ \\
\hline June & $\begin{array}{l}\text { High } \\
\text { Low }\end{array}$ & $\begin{array}{l}22 \\
19\end{array}$ & $\begin{array}{r}8 \\
11\end{array}$ & $\chi^{2}$ & $>0.50 \mathrm{~ns}$ \\
\hline July & $\begin{array}{l}\text { High } \\
\text { Low }\end{array}$ & $\begin{array}{l}12 \\
26\end{array}$ & $\begin{array}{l}18 \\
26\end{array}$ & $\chi^{2}$ & $>0.50 \mathrm{~ns}$ \\
\hline August & $\begin{array}{l}\text { High } \\
\text { Low }\end{array}$ & $\begin{array}{l}12 \\
13\end{array}$ & $\begin{array}{l}16 \\
23\end{array}$ & $\chi^{2}$ & $>0.70 \mathrm{~ns}$ \\
\hline September & $\begin{array}{l}\text { High } \\
\text { Low }\end{array}$ & $\begin{array}{l}11 \\
14\end{array}$ & $\begin{array}{l}13 \\
13\end{array}$ & $\chi^{2}$ & $>0.80 \mathrm{~ns}$ \\
\hline October & $\begin{array}{l}\text { High } \\
\text { Low }\end{array}$ & $\begin{array}{l}13 \\
14\end{array}$ & $\begin{array}{l}24 \\
12\end{array}$ & $\chi^{2}$ & $>0.20 \mathrm{~ns}$ \\
\hline November & $\begin{array}{l}\text { High } \\
\text { Low }\end{array}$ & $\begin{array}{r}7 \\
13\end{array}$ & $\begin{array}{r}10 \\
4\end{array}$ & $x^{2}$ & $<0.05^{*}$ \\
\hline December & $\begin{array}{l}\text { High } \\
\text { Low }\end{array}$ & $\begin{array}{l}15 \\
12\end{array}$ & $\begin{array}{r}16 \\
8\end{array}$ & $\chi^{2}$ & $>0.50 \mathrm{~ns}$ \\
\hline
\end{tabular}

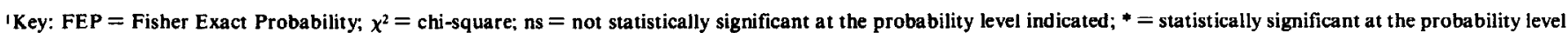
indicated. 
Table 3. Distributions of Barbary sheep and mule deer by topographic level in Palo Duro Canyon, Texas, indicate no significant overall difference $(p>0.50)$ between species.

\begin{tabular}{|c|c|c|c|c|c|c|}
\hline \multirow[b]{2}{*}{ Topographic level } & \multicolumn{3}{|c|}{ Barbary sheep } & \multicolumn{3}{|c|}{ Mule deer } \\
\hline & Observed & Expected & $\%$ sightings & Observed & Expected & $\%$ sightings \\
\hline Canyon rim & 163 & 164.93 & 30.81 & 107 & 105.07 & 31.75 \\
\hline High benches & 142 & 149.05 & 26.84 & 102 & 94.95 & 30.27 \\
\hline Low benches & 201 & 193.64 & 38.00 & 116 & 123.36 & 34.42 \\
\hline Canyon floor & 23 & 21.38 & 4.35 & 12 & 13.62 & 3.56 \\
\hline Totals & 529 & 529 & 100.00 & 337 & 337 & 100.00 \\
\hline
\end{tabular}

slopes steeper than $45^{\circ}$. However, Mearns (1907) clearly indicates that mule deer are capable of traversing the steepest canyon wall country.

Kerr (1979) commented that mule deer are primarily associated with forest, woodland, or brushland areas, and reasoned that this is probably due to their need to remain close to visual or escape cover. Where vegetation does not provide sufficient cover, habitat needs will only be met if topographic cover replaces or supplements limited vegetative cover (Severson and Carter 1978). Mule deer almost certainly depend upon the Rough Breaks of bluff faces for topographic and escape cover in those parts of Palo Duro Canyon where this requirement is not met by mesquite (Prosopis glandulosa), juniper (Juniperus spp.), or sand shinnery oak (Quercus havardii) vegetation or by an extensive amount of topographic relief in the Mixed Land Slope zone above the canyon rim. Thus a minimum of $44 \%$ of all mule deer groups were sighted on the Rough Breaks in any season during this study, and nearly $65 \%$ of the aggregated sightings were from this habitat (Table 4). It should be noted, however, that the benches on bluff faces form relatively level ledges or terraces on the canyon walls. We rarely saw mule deer attempt to directly negotiate the most precipitous bluff faces, as Barbary sheep frequently did.

The data from this study indicate that Barbary sheep and mule deer utilize the same topographic levels and habitat types throughout the year. Further, their distribution are not significantly different for most months and when considered on an annual basis, although there are marked differences during some seasons. Thus the physical proximity of these 2 species in Palo Duro Canyon subjects them to ecological relations that may affect other aspects of their biology.

One component of the ecological relationship between Barbary sheep and mule deer is the possibility of competition for space.
Barbary sheep and mule deer were rarely seen close to each other except during the winter months. In this season both species were attracted to supplemental food sources provided by fields of winter wheat (Triticum aestivum) adjacent to the canyon rim. The few observed instances of interspecific aggression indicated that Barbary sheep are behaviorally dominant and occa sionally chase mule deer short distances. Such interactions were infrequent and of little apparent consequence to either species.

Another important consideration is the dietary relationship of the 2 ungulates. Barbary sheep eat a wide variety of plants and are apparently limited only by geographic and sea sonal availability of forage (Krysl et al. 1980, Simpson et al. 1980), but mule deer exhibit rather narrow forage utilization patterns throughout the southwestern United States (Kufeld et al. 1973, Krysl 1979). Additionally, diets of Barbary sheep and mule deer are similar in Palo Duro Canyon, Texas (Krysl et al. 1980) and Largo Canyon, New Mexico (Bird and Upham 1980) as revealed by similarity indices. Thus mule deer are at a potential competitive disadvantage in Palo Duro Canyon and other areas where the 2 species are sympatric.

A third consideration is elaeophorosis, which has been documented in both ungulates from Palo Duro Canyon (Gray 1980, Pence and Gray 1981). Lesions on the heads of some Barbary sheep are so extensive that hunters consider them unsuitable for trophy mounts. Hibler and Adcock (1971:266) speculate that deer are the normal definitive hosts for the arterial nematode Elaeophora schneideri, and the absence of gross pathologic lesions associated with elaeophorosis in deer supports this view. Because of the economic importance of Barbary sheep hunting to some ranchers (Schreiner 1968. Christian 1980), the impact of this disease should be considered in Barbary sheep population management in areas where mule deer numbers are moderate to high.

Topographic distribution and habitat utilization patterns of

Table 4. Seasonal distributions of Barbary sheep and mule deer sightings over 3 big game habitat types in Palo Duro Canyon, Texas, showing significant differences during spring and autumn seasons but no overall annual difference $\left(\chi^{2}\right.$ test $\left.p>0.50\right)$. :

\begin{tabular}{|c|c|c|c|c|c|c|c|c|}
\hline \multirow[b]{3}{*}{ Season species } & \multirow{3}{*}{$\begin{array}{c}\text { Sample size } \\
\mathbf{N}\end{array}$} & \multicolumn{6}{|c|}{ Big game habitat type } & \multirow[b]{3}{*}{$\chi^{2}$ test } \\
\hline & & \multicolumn{2}{|c|}{ Canyon Rim } & \multicolumn{2}{|c|}{ Rough Breaks } & \multicolumn{2}{|c|}{ Canyon Floor } & \\
\hline & & $\mathbf{N}$ & $\%$ & $\mathbf{N}$ & $\%$ & $\mathbf{N}$ & $\%$ & \\
\hline $\begin{array}{l}\text { Winter } \\
\text { Barbary sheep } \\
\text { Mule deer }\end{array}$ & $\begin{array}{l}179 \\
111\end{array}$ & $\begin{array}{l}79 \\
59\end{array}$ & $\begin{array}{l}44.1 \\
53.2\end{array}$ & $\begin{array}{l}95 \\
49\end{array}$ & $\begin{array}{l}53.1 \\
44.1\end{array}$ & $\begin{array}{l}5 \\
3\end{array}$ & $\begin{array}{l}2.8 \\
2.7\end{array}$ & $p>0.30 \mathrm{~ns}$ \\
\hline $\begin{array}{l}\text { Spring } \\
\text { Barbary sheep } \\
\text { Mule deer }\end{array}$ & $\begin{array}{r}188 \\
44\end{array}$ & $\begin{array}{r}63 \\
4\end{array}$ & $\begin{array}{r}33.5 \\
9.1\end{array}$ & $\begin{array}{r}118 \\
38\end{array}$ & $\begin{array}{l}62.8 \\
86.4\end{array}$ & $\begin{array}{l}7 \\
2\end{array}$ & $\begin{array}{l}3.7 \\
4.5\end{array}$ & $p<0.01^{*}$ \\
\hline $\begin{array}{l}\text { Summer } \\
\text { Barbary sheep } \\
\text { Mule deer }\end{array}$ & $\begin{array}{r}88 \\
109\end{array}$ & $\begin{array}{r}9 \\
16\end{array}$ & $\begin{array}{l}10.2 \\
14.7\end{array}$ & $\begin{array}{l}74 \\
87\end{array}$ & $\begin{array}{l}84.1 \\
79.8\end{array}$ & $\begin{array}{l}5 \\
6\end{array}$ & $\begin{array}{l}5.7 \\
5.5\end{array}$ & $p>0.30 \mathrm{~ns}$ \\
\hline $\begin{array}{l}\text { Autumn } \\
\text { Barbary sheep } \\
\text { Mule deer }\end{array}$ & $\begin{array}{l}74 \\
73\end{array}$ & $\begin{array}{l}12 \\
28\end{array}$ & $\begin{array}{l}16.2 \\
38.3\end{array}$ & $\begin{array}{l}56 \\
44\end{array}$ & $\begin{array}{l}75.7 \\
60.3\end{array}$ & $\begin{array}{l}6 \\
1\end{array}$ & $\begin{array}{l}8.1 \\
1.4\end{array}$ & $p<0.01^{*}$ \\
\hline $\begin{array}{l}\text { Overall } \\
\text { Barbary sheep } \\
\text { Mule deer }\end{array}$ & $\begin{array}{l}529 \\
337\end{array}$ & $\begin{array}{l}163 \\
107\end{array}$ & $\begin{array}{l}30.8 \\
31.8\end{array}$ & $\begin{array}{l}343 \\
218\end{array}$ & $\begin{array}{l}64.8 \\
64.7\end{array}$ & $\begin{array}{l}23 \\
12\end{array}$ & $\begin{array}{l}4.3 \\
3.3\end{array}$ & $p>0.50 \mathrm{~ns}$ \\
\hline
\end{tabular}


Barbary sheep and mule deer, as well as desert bighorn sheep (Ovis canadensis), will be increasingly important considerations as Barbary sheep continue to expand their range in the southwestern United States (see Simpson et al. 1978, Seegmiller and Simpson 1979, Simpson and Krysl 1981a, 1981b).

\section{Literature Cited}

Anthony, R.G., and M.S. Smith. 1977. Ecological relationships between mule deer and white-tailed deer in southeastern Arizona. Ecol. Monogr. 47:255-277.

Bird, W., and L. Upham. 1980. Barbary sheep and mule deer food habits of Largo Canyon, New Mexico. p. 92-96 In: Proc. Barbary Sheep Ecol. Manage. Sym. C.D. Simpson (ed.) Texas Tech Univ. Press, Lubbock.

Christian, T.T. 1980. Development and economic role of a oudad hunting in a cattle ranching operation. p. 104-105 In: Proc. Barbary Sheep Ecol. Manage. Sym. C.D. Simpson (ed.). Texas Tech Univ. Press, Lubbock.

DeArment, R. 1971. Reaction and adaptability of introduced aoudad sheep. Texas Parks and Wildl. Dep., Div. Fed. Aid Wildl. Restoration Proj. W-45-R-21, 1-20.

Dickinson, T.G., and C.D. Simpson. 1980. Dispersal and establishment of Barbary sheep in southeast New Mexico. p. 33-45. In: Proc. Barbary Sheep Ecol. Manage. Sym. C.D. Simpson (ed.). Texas Tech Univ. Press, Lubbock.

Evans, P.K. 1964. Reaction and adaptability of introduced aoudad sheep. Texas Parks and Wildl. Dep., Div. Fed. Aid Wildl. Restoration Proj. W-45-R-14, 1-9.

Gray, G.G. 1980. Aspects of Barbary sheep (Ammotragus lervia) biology in Palo Duro Canyon, Texas. Ph.D. Diss. Texas Tech Univ., Lubbock.

Hampy, D.B. 1978. Home range and seasonal movement of Barbary sheep in the Palo Duro Canyon. M.S. Thesis. Texas Tech Univ., Lubbock.

Hibler, C.P., and J.L. Adcock. 1971. Elaeophorosis. p. 263-278. In: Parasitic diseases of wild mammals. J. Davis and R.C. Anderson (eds.). lowa State Univ. Press, Ames.

Jacquot, L.L., L.C. Geiger, B.R. Chance, V.D. Woods, D.A. Leath, and L.C. Mike. 1965. Soil survey of Armstrong County, Texas. USDA Soil Conserv. Serv., Ser. 1961. No. 80, 1-80.

Kerr, R.M. 1979. Mule deer habitat guidelines. U.S. Dep. Int., Bur. Land Manage., Tech. Note 336:1-61.

Krysl, L.J. 1979. Food habits of mule deer and elk, and their impact on vegetation in Guadalupe Mountains National Park. M.S. Thesis. Texas Tech Univ., Lubbock.

Krysl, L.J., C.D. Simpson, and G.G. Gray. 1980. Dietary overlap of sympatric Barbary sheep and mule deer in Palo Duro Canyon, Texas. p. 97-103 In: Proc. Barbary Sheep Ecol. Manage. Sym. C.D. Simpson (ed.). Texas Tech Univ. Press, Lubbock.
Kufeld, R.C., D.C. Wallmo, and C. Feddema. 1973. Foods of the Rocky Mountain mule deer. USDA For. Serv. Res. Pap. RM-111, 1-31.

Leftwich, T.J., and C.D.Simpson. 1978. The impact of domestic livestock and farming on Texas pronghorn. Proc. Bien. Pronghorn Antelope States Workshop. Alberta, Can. 8:307-320.

Mackie, R.J. 1970. Range ecology and relations of mule deer, elk, and cattle in the Missouri River breaks, Montana. Wildl. Monogr. 20:1-79.

Mearns, E.A. 1907. Mammals of the Mexican boundary of the United States. U.S. Nat. Hist. Mus. Bull. 26:530.

Pence, D.B., and G.G. Gray. 1981. Elaeophorosis in Barbary sheep and mule deer from the Texas Panhandle. J. Wildl. Dis. 17:49-56.

Rowell, C.A. 1967. Vascular plants of the Texas Panhandle and South Plains. Ph.D. Thesis. Oklahoma State Univ., Stillwater.

Schreiner, C., III. 1968. Uses of exotic animals in a commercial hunting program. p. 13-61 In: Sym. Introduction of exotic animals-ecological and socioeconomic considerations. Caesar Kleberg Research Program in Wildlife Ecology (ed.). Texas A\&M Univ., College Station.

Seegmiller, R.F., and C.D. Simpson. 1979. The Barbary Sheep: some conceptual implications of competition with desert bighom. Trans. Desert Bighorn Council 23:47-49.

Severson, K.E., and A.V.Carter. 1978. Movements and habitat use by mule deer in the northern Great Plains, South Dakota. USDA, For. Serv., Rocky Mtn. For. Range Exp. Sta., Tempe, Ariz.

Siegel, S. 1956. Nonparametric statistics for the behavioral sciences. New York. McGraw-Hill.

Simpson, C.D., and L.J. Kryst. 1981a. Barbary sheep: a new competitor on North American rangelands. Proc. Sym. Wildl./Livestock Relationships, Univ. Idaho Press, Moscow. (In press).

Simpson, C.D., and L.J. Krysl. 1981b. Status and distribution of Barbary sheep in the southwestern United States. Trans. Desert Bighorn Council 25:9-15.

Simpson, C.D., L.J. Krysl, and T.G. Dickinson. 1980. Food habits of Barbary sheep in the Guadalupe Mountains, New Mexico, p. 87-91 In: Proc. Barbary Sheep Ecol. Manage. Sym. C.D. Simpson (ed.). Texas Tech Univ. Press, Lubbock.

Simpson, C.D., L.J. Krysl, D.B. Hampy, and G.G. Gray. 1978. The Barbary sheep: a threat to desert bighorn survival. Trans. Desert Bighorn Council 22:26-31.

Simpson, C.D., and T.J. Leftwich. 1978. Historic range change in the Texas pronghorn. Proc. Bien. Pronghorn Antelope Workshop, Alberta, Can. 8:121-146.

Simpson, C.D., and T.J. Leftwich. 1981. Historical review of mule deer in Texas. Occ. Pap. Texas Tech Mus., Lubbock. (In press).

Sokal, R.R., and F.J. Rohlf. 1969. Biometry, the principles and practice of statistics in biological research. San Francisco. W.H. Freeman and Co. $776 \mathrm{p}$.

Wright, R.A. 1978. The vegetation of Palo Duro Canyon. PanhandlePlains Hist. Rev. 51:87-116. 